\title{
Editorial: Riparian Buffer Nutrient Dynamics and Water Quality
}

\author{
Eric O. Young ${ }^{1 *}$, Donald S. Ross ${ }^{2}$ and Dan B. Jaynes ${ }^{3}$ \\ ${ }^{1}$ Agricultural Research Service, United States Department of Agriculture, Institute for Environmentally Integrated Dairy \\ Management, Marshfield, WI, United States, ${ }^{2}$ Department of Plant and Soil Science, University of Vermont, Burlington, VT, \\ United States, ${ }^{3}$ Agricultural Research Service, National Laboratory for Agricultural and the Environment, United States \\ Department of Agriculture, University Blvd, Ames, IA, United States
}

Keywords: nitrogen, phosphorus, riparian zones, soils, water quality

\section{Editorial on the Research Topic}

\section{Riparian Buffer Nutrient Dynamics and Water Quality}

Effectively mitigating nutrient pollution from agroecosystems to protect water quality remains a global challenge, particularly in the face of weather extremes related to climate change (Coumou and Rahmstorf, 2012). While riparian buffers (permanently vegetated areas between cropland and streams) are considered an important nutrient mitigation best management practice, nitrogen $(\mathrm{N})$ and phosphorus $(\mathrm{P})$ removal varies widely and can be difficult to predict (Hill, 1996; Hoffmann et al., 2009). More research is needed on site-specific factors and interactions affecting $\mathrm{N}$ and $\mathrm{P}$ cycling and transport to help refine/validate riparian water quality models (Vidon et al.,

OPEN ACCESS

Edited by:

Philippe C. Baveye,

AgroParisTech Institut des Sciences et Industries du Vivant et de L'environnement, France

Reviewed by:

Magdeline Laba,

Cornell University, United States

*Correspondence: Eric O. Young eric.young@ars.usda.gov

Specialty section: This article was submitted to Soil Processes,

a section of the journal Frontiers in Environmental Science

Received: 02 April 2019 Accepted: 14 May 2019 Published: 29 May 2019

Citation:

Young EO, Ross DS and Jaynes DB

(2019) Editorial: Riparian Buffer Nutrient Dynamics and Water Quality.

Front. Environ. Sci. 7:76.

doi: 10.3389/fenvs.2019.00076 2018; Hassanzadeh et al., 2019). Specifically, studies focusing on interactions among hydrology, soils, redox conditions, and riparian vegetation are needed to better predict mitigation potential at field, watershed and inter-biome scales. In addition to inherent site factors, practical management aspects affecting buffer efficacy are also important but understudied. Our Research Topic addresses some of these important outstanding questions, including two papers evaluating $\mathrm{P}$ transport risk, a hypothesis/theory article that advances our understanding of $\mathrm{N}$ biogeochemistry among riparian biomes, and a study evaluating impacts of vegetation harvesting on plant community ecology and nutrient uptake potential.

Georgakakos et al. investigated the impact of establishing a cattle-exclusion riparian buffer (CERB) on sediment, total (TP) and soluble reactive P (SRP) concentrations and loads in a small agricultural stream in New York, USA. Pre- $(n=51)$ and post-CERB stream water sampling $(n$ $=27$ ) coupled with a calibrated stream flow model for the region were used to estimate sediment, stream water TP and SRP export (for non-storm events). Whereas, the CERB significantly reduced sediment and TP transport, SRP loads and concentrations numerically increased. While concluding CERBs can reduce sediment and TP, the authors also highlighted potential complicating factors contributing to sustained SRP loading, including formation of new surface runoff flow pathways in the CERB, periodic failure of livestock fencing, and SRP desorption from legacy P sources.

Riparian plant communities can strongly affect buffer performance via influencing runoff hydrology, nutrient uptake, and recycling. Hille et al. studied the impacts of riparian vegetation harvesting regimes on diversity metrics and biomass yield potential using 112 plots $\left(1 \mathrm{~m}^{2}\right)$ distributed between two sites in Denmark. Hierarchical clustering identified specific plant communities which were harvested once, twice, or four times during the growing season by cutting to a $5 \mathrm{~cm}$ stem height with removal of biomass. Compared to controls, all harvesting increased diversity and richness for tall grass and tall herb fringe communities. The authors suggest that low frequency harvesting may provide a management option to remove riparian nutrients while still maintaining plant diversity. 
Riparian $\mathrm{N}$ attenuation mechanisms are fairly well established at the site-level, however mechanisms operating across biomes are less clear. Based on a synthesis over the past few decades, Pinay et al. propose that riparian corridor structure shapes overall stream morphology and $\mathrm{N}$ attenuation by controlling the distribution of sediments, water flow, and redox conditions. They further hypothesize that gross ammonification (transformation of organic- $\mathrm{N}$ to ammonium-N) and net nitrification rates (nitrate- $\mathrm{N}$ remaining after plant uptake) largely dictate $\mathrm{N}$ fluxes across riparian biomes. Moreover, they suggest that relative differences between net nitrification and gross ammonification should reflect $\mathrm{N}$ vulnerable to leaching and/or denitrification losses. Quantifying these $\mathrm{N}$ processes across biomes and climatic gradients will provide important data to assess how riparian zones and stream water quality react to climate change.

The importance of soils and redox conditions on SRP desorption from buffer soils is an important but understudied process (Bol et al., 2018; Vidon et al., 2018). Young and Ross characterized $\mathrm{P}$ desorption potential to soil porewater (PW) and mobilization to overlying floodwater (FW) using laboratory microcosms over a 75-day incubation period. Results showed that PW-SRP increased by as much as 8.4-fold, however FWSRP tended to decrease over time. They hypothesized that oxidation of reduced iron at aerobic interfaces limited PWSRP mobilization to overlying water. The concentration of labile extractable inorganic $\mathrm{P}$ was a reliable indicator of SRP release to both PW and FW. They suggest that water quality/riparian models should explicitly account for both labile soil P differences and variable source area hydrology typical of riparian buffers to better predict $\mathrm{P}$ release and transport risk.

\section{REFERENCES}

Bol, R., Gruau, G., Mellander, P.-E., Dupas, R., Bechmann, M., Skarbøvik, E., et al. (2018). Challenges of reducing phosphorus based water eutrophication in the agricultural landscapes of northwest Europe. Front. Mar. Sci. 5:276. doi: 10.3389/fmars.2018.00276

Coumou, D., and Rahmstorf, S. (2012). A decade of weather extremes. Nature Clim. Change 2, 491-496. doi: 10.1038/nclimate1452

Hassanzadeh, Y. T., Vidon, P. G., Gold, A. J., Pradhanang, S. M., and Addy Lowder, K. (2019). RZ-TRADEOFF: a new model to estimate riparian water and air quality functions. Water 11:769. doi: 10.3390/w11040769

Hill, A. R. (1996). Nitrate removal in stream riparian zones. J. Environ. Qual. 25, 743-755. doi: 10.2134/jeq1996.00472425002500040014x

Hoffmann, C. C., Kjaergaard, C., Uusi-Kämppä, J., Hansen, H. C. B., and Kronvang, B. (2009). Phosphorus retention in riparian buffers: a review of their
Water flow pathways entering and exiting buffers (i.e., hydrology) often set the stage for potential water quality functions. However, many unanswered questions remain with respect to predicting specific buffer water quality functions and potential nutrient attenuation tradeoffs. For example, buffers that effectively remove nitrate- $\mathrm{N}$ in shallow subsurface flows may simultaneously elevate SRP release risk due to lower redox conditions. Future field and modeling studies should better account for this mechanism and other potential riparian "biogeochemical tradeoffs." Besides additional targeted research on soil, hydrologic, and plant community impacts on buffer nutrient attenuation potential, land management also plays a critical role by directly affecting on-site conditions and buffer integrity, particularly in active agricultural settings where cropping and grazing practices can easily override the importance of other factors influencing nutrient removal. Future buffer research should strive to integrate both hydrogeochemical and management-related factors affecting nutrient attenuation potential to better predict buffer water quality functions in diverse landscapes.

\section{AUTHOR CONTRIBUTIONS}

EY coordinated the Research Topic with Frontiers. EY, DR, and DJ contributed to writing and approval of this editorial.

\section{ACKNOWLEDGMENTS}

We wish to express our sincere gratitude to all of the reviewers for their time and contributions to this Research Topic.

efficiency. J. Environ. Qual. 38, 1942-1955. doi: 10.2134/jeq2008.0087

Vidon, P. G., Welsh, M. K., and Hassanzadeh, Y. T. (2018). Twenty years of riparian zone research (1997-2017): where to next? J. Environ. Qual. 48, 248-260. doi: $10.2134 /$ jeq2018.01.0009

Conflict of Interest Statement: The authors declare that the research was conducted in the absence of any commercial or financial relationships that could be construed as a potential conflict of interest.

Copyright (C) 2019 Young, Ross and Jaynes. This is an open-access article distributed under the terms of the Creative Commons Attribution License (CC BY). The use, distribution or reproduction in other forums is permitted, provided the original author(s) and the copyright owner(s) are credited and that the original publication in this journal is cited, in accordance with accepted academic practice. No use, distribution or reproduction is permitted which does not comply with these terms. 